\title{
46. GEOCHEMISTRY OF CARBON: DEEP SEA DRILLING PROJECT LEG 48
}

\author{
J. G. Erdman and K. S. Schorno, Phillips Petroleum Company, Bartlesville, Oklahoma
}

\section{INTRODUCTION}

Twelve frozen core sections for geochemical investigation were obtained through the Advisory Panel on Organic Geochemistry. Eight frozen sections from the Lower Cretaceous-Aptian at Hole $402 \mathrm{~A}$ are from a canyon at a water depth of 2339.5 meters on the mid-continental slope of the Bay of Biscay. Four frozen sections from the lower Eocene are from Sites 403 and 404 on the rifted southwest margin of the Rockall Plateau at a water depth of 2317 and 2322 meters, respectively. Figure 1 shows the sample site locations.

\section{SAMPLING AND STUDY PROCEDURES}

The descriptive sampling and analysis procedures used in this laboratory for DSDP cores are discussed in the Initial Reports for Leg 44 (Erdman and Schorno, 1978). Photographs of each core, lithologic descriptions, and organic and carbonate carbon analysis of textural types were performed as usual, but for brevity are not included. No mixing of lithologies was observed in any of the cores. The organic carbon content of the individual lithologies taken from the milled surface of each half section of core proved to be 1.1 to 16 times higher than for the corresponding homogenized core. This apparent bias is caused by organic-rich lithologic zones or patches which while volumetrically small, will dominate the average value for the core.

Because these particular cores were lean in extractable organic matter (lipid), analyses of this fraction were limited to carbon isotopic composition, carbon and hydrogen composition, and a gas chromatograph profile of the $n$-heptane soluble lipid.

\section{RESULTS}

The numerical data generated for these samples along with sub-bottom depths and ages are provided in Table 1 . Gas chromatograms (gc-profiles) of the $n$-heptane soluble portion of the lipid are given in Figure 2.

\section{Hole 402A}

Hole 402A is on a spur of the northern continental margin in the Bay of Biscay, north of the Meriadzke escarpment and the Shamrock Canyon. The eight cores from this site are from upper to lower Aptian sediments with sub-bottom depths ranging from 254.3 to 465.1 meters. They are from lithologic Unit 3, Sub-units 1 through 4. Seven cores are calcareous mudstones to clayey limestones. The eighth core, Section $35-4$, is a mudstone. The carbonate carbon content averages 3.4 per cent with a range of 0.08 to 5.2 per cent. The organic carbon content is 0.59 per cent at 254.3 meters, increases to a high of 2.02 per cent at 413.2 meters, then decreases to 0.46 per cent at 464.8 meters.
The lipid content for this unit averages $39 \mathrm{ppm}$ with a range of 9 to $55 \mathrm{ppm}$. The per cent of the total organic carbon as lipid averages 0.4 per cent with only a small spread between cores.

The carbon isotopic composition of the lipid fraction of this unit as given by $\delta^{13} \mathrm{CPDB}^{1}$ varies considerably throughout the unit. The average value is $-28.5 \%$ and ranges from $-25.8 \%$ in Sub-unit 3 to $-30.5 \%$ in Sub-unit 1 . The average $\delta$ value for the corresponding kerogens is $-23.8 \%$ and ranges from -23.1 to $-24.4 \%$.

The hydrogen to carbon ratio $(\mathrm{H} / \mathrm{C})$ of the lipid ranges from 1.45 to 1.8. This ratio for Sections $13-3$ and 15-1 averages 1.77 and is slightly higher than the average value of 1.57 for the remaining cores in this unit.

The average values for ammonium and organic nitrogen content are 73 and $345 \mathrm{ppm}$, respectively.

As shown in Figure 2A the gc-profile for Section 13-3 from Subunit 1 contains an unresolved naphthene maximum at $\mathrm{C}_{22}$, a trace of $\mathrm{C}_{16}$ through $\mathrm{C}_{35} n$-alkanes, and dominant peaks at $\mathrm{C}_{21}$ (A), $\mathrm{C}_{28}$ (D), and $\mathrm{C}_{31}(\mathrm{~F})$. The gc-profile for Section 15-1 (Figure 2B) is similar to Section 13-3 with slight differences such as a larger naphthene fraction for Section 15-1. The ratio of odd to even $n$-alkanes between $\mathrm{C}_{27}$ and $\mathrm{C}_{32}$ as given by the average OEP value ( $\left.\overline{\mathrm{OEP}}\right)$ between these carbon numbers (Scalan and Smith, 1970) for both Sections 13-3 and 15-1 are 4.4 and 1.6, respectively. The gc-profiles of Sections 18-1 through 35-1 are similar and are illustrated by the profile of Section 18-1 shown in Figure 2C. These profiles differ from the upper two cores in that the naphthene maximum has shifted from $\mathrm{C}_{22}$ to approximately $\mathrm{C}_{27}$ and the $n$-alkanes between $\mathrm{C}_{27}$ to $\mathrm{C}_{31}$ are more apparent.

\section{Sites $\mathbf{4 0 3}$ and $\mathbf{4 0 4}$}

Sites 403 and 404 are on the rifted southwest margin of the Rockall Plateau. The four cores obtained from the two sites are from the same lower Eocene lithologic unit three. Sections 404-17-4 and 403-37-6 are from Subunit 1 at depths of 298.5 and 344.5 meters, respectively. Sections 404-22-6 and 403-41-5 are from Sub-unit 2 at depths of 349.0 and 381.4 meters, respectively.

These four cores are tuffaceous to glauconitic mudstones. The average carbonate carbon content is 4.5 per cent and ranges from 3 to 5 per cent. Sections 403-41-5 and 404-17-4 contain 0.07 per cent organic carbon. Sections 403-37-6 and 404-22-6 contain 0.5 and 0.2 per cent organic carbon, respectively. The lipid content of all four cores is similar,

$$
{ }^{13} \mathrm{C}_{\mathrm{PDB}}=\frac{\left(\mathrm{R}_{\mathrm{s}}-\mathrm{R}_{\mathrm{r}}\right)}{\mathrm{R}_{\mathrm{r}}} \times 1000 \% . \mathrm{R}_{\mathrm{s}} \text { refers to a belemnite from }
$$

the Upper Cretaceous Peedee Formation of South Carolina. 


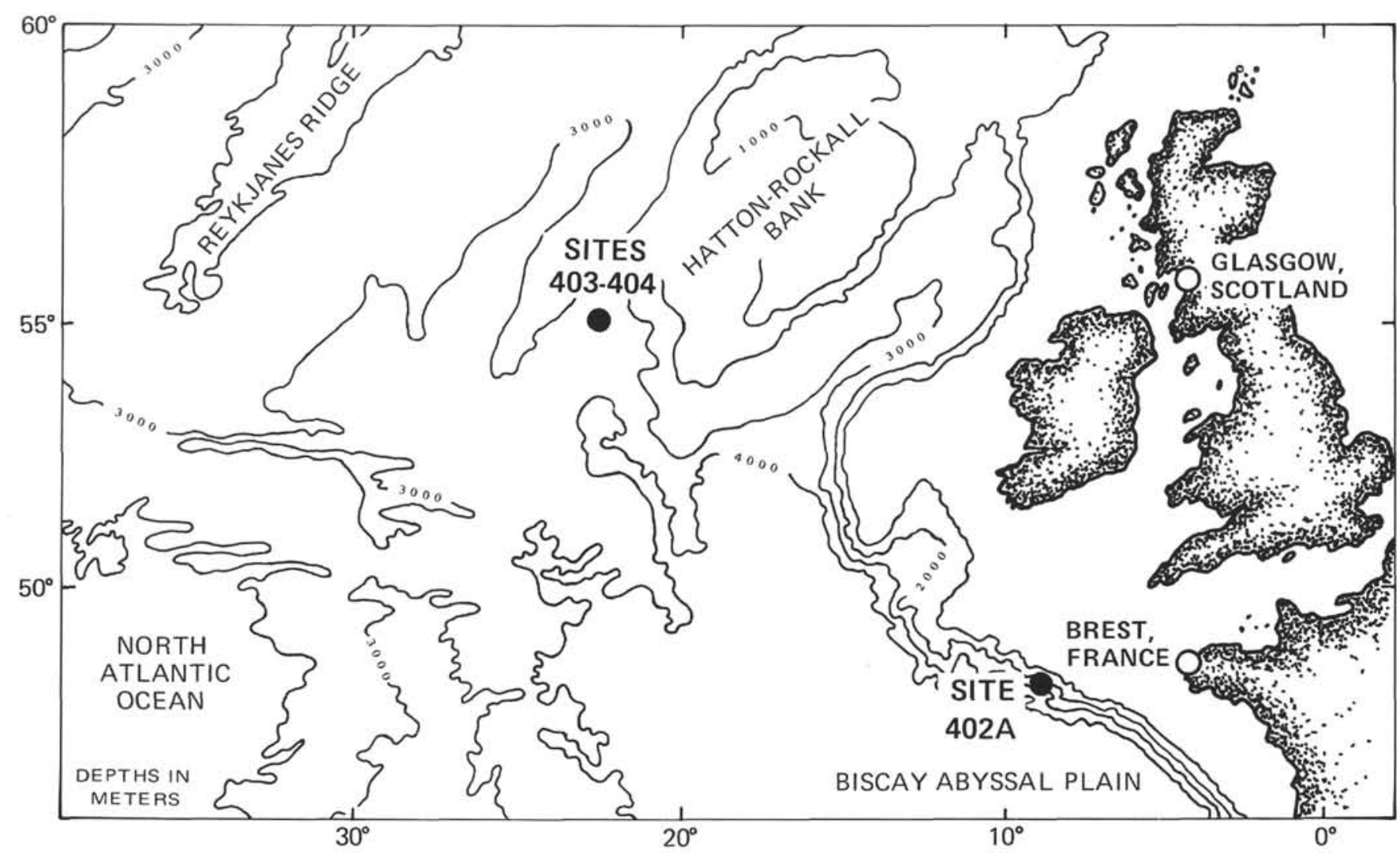

Figure 1. Leg 48 drill sites. Location of holes from which samples for geochemical study were obtained.

averaging $20 \mathrm{ppm}$ with a range from 10 to $34 \mathrm{ppm}$. The per cent of the total organic matter as lipid is 0.7 to 2.4 .

The $\delta^{13}$ CPDB values of the lipid fractions of Sections 40337-6 and 404-17-4 from Sub-unit 1 and Sections 403-41-5 and 404-22- 6 from Sub-unit 2 are similar within each sub-unit; that is, $-27.4+0.5 \%$ and $-29.4+0.4 \%$, respectively. The $\delta$ values for the kerogens of Sections 403-37-6 and 404-17-4 are -23.3 and $-29.2 \%$, respectively. The difference between the lipid and kerogen $\delta$ values (L-K) for these two cores are $-4.6 \%$ and $+2.3 \%$. The $\delta$ values of the kerogen for the two cores from Sub-unit 2 are -27.8 and -27.1 and the $\mathrm{L}-\mathrm{K}$ value for both cores is $-1.2 \%$ and $-2.7 \%$.

The average ammonium and organic nitrogen content for all four cores from this site are $30 \mathrm{ppm}$ and $102 \mathrm{ppm}$, respectively.

The gc-profiles within sub-units, that is of Sections 403 37-6 and 404-17-4 and 403-41-5 and 404-22-6 compare favorably and are illustrated in Figures $2 \mathrm{D}$ and $3 \mathrm{E}$ by profiles of Sections 404-17-4 and 404-22-6.

\section{DISCUSSION AND CONCLUSIONS}

The eight predominantly calcareous, upper Aptian cores from Hole $402 \mathrm{~A}$ are rich in organic matter averaging 1.15 per cent organic carbon as compared to 0.1 per cent for average DSDP cores. Organic genesis is in an early stage in these cores as indicated by a large difference in the lipid and kerogen carbon isotopic compositions, a high degree of saturation of the lipid fraction, and a high value for $\overline{\mathrm{OEP}}$.

The large negative difference between the lipid and kerogen values indicates that the lipid and kerogen fractions co-developed from common source material. The values of the lipid fractions are typical of deltaic sequences where the ratio of marine to terrestrial organic matter, as represented by the composite value, changes with the movement of the shore line. A periodic change is observed in the values of the lipid fractions of these cores. The average $\delta$ value for the lipid fractions of Sections 13-3 and 24-1 $(-30.2 \pm 0.3 \% 0)$ is typical of a period when fresh water predominated in the delta whereas, the lipid $\delta$ values for Sections $18-1$ and 30-1 are typical of a near-shore marine period.

The four tuffaceous lower Eocene mudstones from Sites 403 and 404 average 0.2 per cent organic carbon, slightly above the average value for DSDP cores. Organic genesis in these cores is in an early stage as indicated by the L-k $\delta$ values and the high $\overline{\mathrm{OEP}}$ value. Organic diagenesis is more advanced than in cores from Hole 402A. This conclusion is based on the smaller difference in the L-K $\delta$ values and a larger amount of soluble versus total organic matter.

The negative L-K $\delta$ values for Sections 403-37-6, 40341-5, and 404-22-6 suggest that the sedimentary organic matter in these units is autochthonous. The positive value for Section 404-17-4 suggests that it contains a lipid fraction at least a part of which is not indigenous, i.e., has migrated into the unit. The depositional environment of the sedimentary organic matter in the two subunits is similar to that of Hole $402 \mathrm{~A}$, that is, deltaic.

\section{ACKNOWLEDGEMENT}

The authors thank Dr. S. Palmer, Florida Atlantic University, for her review and suggestions concerning this manuscript and C.P. Elston, Phillips Research Center, for her help in obtaining and assembling data presented herein. 
TABLE 1

Chemistry of Core Sections From IPOD Leg 48

Geologic Age, Depth, Carbonate, Organic, Nitrogen Composition

\begin{tabular}{|c|c|c|c|c|c|c|c|c|c|c|c|c|c|c|c|}
\hline \multirow[b]{3}{*}{$\begin{array}{l}\text { Site-Core- } \\
\text { Section }\end{array}$} & \multirow[b]{3}{*}{$\begin{array}{l}\text { Geologic } \\
\text { Age }\end{array}$} & \multirow[b]{3}{*}{$\begin{array}{l}\text { Sub-Bottom } \\
\text { Depth }(\mathrm{m})\end{array}$} & \multirow{2}{*}{\multicolumn{2}{|c|}{ Carbonate }} & \multirow{2}{*}{\multicolumn{2}{|c|}{ Organic Carb. }} & \multirow{3}{*}{$\begin{array}{l}\text { Lipid/Total } \\
\text { Organic Carbon } \\
\text { (wt. \%) }\end{array}$} & \multirow{2}{*}{\multicolumn{3}{|c|}{$\begin{array}{c}\text { Carbon Isotopic } \\
\text { Composition }\left(\delta^{13} \mathrm{C}_{\mathrm{PDB}}\right)\end{array}$}} & \multirow{3}{*}{$\begin{array}{r}\text { Lipid } \\
\mathrm{H} / \mathrm{C}\end{array}$} & \multicolumn{3}{|c|}{ Kjeldalh Nitrogen (ppm) } & \multirow[b]{3}{*}{$\overline{\mathrm{OEP}}^{\mathrm{a}}$} \\
\hline & & & & & & & & & & & & $\underline{\text { Half }}$ & Full & Full-Half & \\
\hline & & & $\begin{array}{l}\text { Carbon } \\
\text { (wt \%) }\end{array}$ & $\begin{array}{l}\mathrm{CaCO}_{3} \\
\text { (wt \%) }\end{array}$ & $\begin{array}{l}\text { Total } \\
\text { (wt \%) }\end{array}$ & $\begin{array}{l}\text { Lipid } \\
(\mathrm{ppm})\end{array}$ & & Lipid & $\begin{array}{l}\text { Kero- } \\
\text { gen }\end{array}$ & $\begin{array}{l}\text { Diff. } \\
\text { L-K }\end{array}$ & & $\underset{\text { ium }}{\text { Ammon- }}$ & Total & Organic & \\
\hline \multicolumn{16}{|c|}{ Hole 402A, Unit 3} \\
\hline \multicolumn{16}{|l|}{ Sub-unit 1} \\
\hline $402 \mathrm{~A}-13-3$ & U. Aptian & $254.3-254.5$ & 5.2 & 44 & 0.59 & 45 & 0.8 & -30.5 & -24.1 & -6.4 & 1.80 & 52 & 348 & 296 & 4.4 \\
\hline \multicolumn{16}{|l|}{ Sub-unit 2} \\
\hline $\begin{array}{l}402 \mathrm{~A}-15-1 \\
402 \mathrm{~A}-18-1 \\
402 \mathrm{~A}-21-1 \\
402 \mathrm{~A}-24-1\end{array}$ & $\begin{array}{l}\text { U. Aptian } \\
\text { U. Aptian } \\
\text { U. Aptian } \\
\text { U. Aptian }\end{array}$ & $\begin{array}{l}272.1-272.5 \\
300.2-300.5 \\
328.9-329.2 \\
336.0-336.3\end{array}$ & $\begin{array}{l}3.8 \\
3.4 \\
3.0 \\
4.3\end{array}$ & $\begin{array}{l}31 \\
29 \\
25 \\
36\end{array}$ & $\begin{array}{l}1.06 \\
1.50 \\
1.43 \\
1.33\end{array}$ & $\begin{array}{l}39 \\
55 \\
29 \\
39\end{array}$ & $\begin{array}{l}0.4 \\
0.4 \\
0.2 \\
0.3\end{array}$ & $\begin{array}{l}-28.4 \\
-28.3 \\
-29.3 \\
-30.1\end{array}$ & $\begin{array}{l}-23.5 \\
-24.3 \\
-24.4 \\
-23.7\end{array}$ & $\begin{array}{l}-4.9 \\
-4.0 \\
-4.9 \\
-6.4\end{array}$ & $\begin{array}{l}1.73 \\
1.57 \\
1.48 \\
1.66\end{array}$ & $\begin{array}{r}69 \\
51 \\
53 \\
120\end{array}$ & $\begin{array}{l}466 \\
130 \\
509 \\
517\end{array}$ & $\begin{array}{l}397 \\
79 \\
456 \\
397\end{array}$ & $\begin{array}{l}1.6 \\
2.0 \\
1.6 \\
1.6\end{array}$ \\
\hline \multicolumn{16}{|l|}{ Sub-unit 3} \\
\hline $402 \mathrm{~A}-30-1$ & U. Aptian & $412.8-413.2$ & 3.2 & 27 & 2.02 & 55 & 0.3 & -25.8 & -23.3 & -2.5 & 1.45 & 81 & 647 & 566 & 1.8 \\
\hline \multicolumn{16}{|l|}{ Sub-unit 4} \\
\hline $\begin{array}{l}402 \mathrm{~A}-33-1 \\
402 \mathrm{~A}-35-4\end{array}$ & $\begin{array}{l}\text { U. Aptian } \\
\text { L. Aptian }\end{array}$ & $\begin{array}{l}441.0-441.4 \\
464.8-465.1\end{array}$ & $\begin{array}{l}3.9 \\
0.1\end{array}$ & $\begin{array}{r}32 \\
1\end{array}$ & $\begin{array}{l}0.88 \\
0.46\end{array}$ & $\begin{array}{r}44 \\
9\end{array}$ & $\begin{array}{l}0.5 \\
0.2\end{array}$ & $\begin{array}{l}-27.2 \\
-28.1\end{array}$ & $\begin{array}{l}-23.1 \\
-23.9\end{array}$ & $\begin{array}{l}-4.1 \\
-4.2\end{array}$ & $\begin{array}{c}1.67 \\
\mathrm{~b}\end{array}$ & $\begin{array}{l}87 \\
70\end{array}$ & $\begin{array}{l}528 \\
195\end{array}$ & $\begin{array}{l}441 \\
125\end{array}$ & $\begin{array}{l}1.8 \\
1.3\end{array}$ \\
\hline \multicolumn{16}{|c|}{ Site 403 and 404 Unit 3} \\
\hline \multicolumn{16}{|c|}{ Sub-unit 1} \\
\hline $\begin{array}{l}403-37-6 \\
404-17-4\end{array}$ & $\begin{array}{l}\text { L. Eocene } \\
\text { L. Eocene }\end{array}$ & $\begin{array}{l}344.5-356.0 \\
298.5-298.8\end{array}$ & $\begin{array}{l}0.6 \\
0.5\end{array}$ & $\begin{array}{l}5 \\
4\end{array}$ & $\begin{array}{l}0.50 \\
0.07\end{array}$ & $\begin{array}{l}34 \\
10\end{array}$ & $\begin{array}{l}0.7 \\
1.4\end{array}$ & $\begin{array}{l}-27.9 \\
-26.9\end{array}$ & $\begin{array}{l}-23.3 \\
-29.2\end{array}$ & $\begin{array}{r}-4.6 \\
2.3\end{array}$ & $\begin{array}{l}\mathrm{b} \\
\mathrm{b}\end{array}$ & $\begin{array}{l}33 \\
33\end{array}$ & $\begin{array}{l}204 \\
119\end{array}$ & $\begin{array}{r}171 \\
86\end{array}$ & $\begin{array}{l}1.9 \\
1.8\end{array}$ \\
\hline \multicolumn{16}{|l|}{ Sub-unit 2} \\
\hline $\begin{array}{l}403-41-5 \\
404-22-6\end{array}$ & $\begin{array}{l}\text { L. Eocene } \\
\text { L. Eocene }\end{array}$ & $\begin{array}{l}381.4-381.6 \\
349.0-349.5\end{array}$ & $\begin{array}{l}0.4 \\
0.6\end{array}$ & $\begin{array}{l}3 \\
5\end{array}$ & $\begin{array}{l}0.07 \\
0.21\end{array}$ & $\begin{array}{l}17 \\
20\end{array}$ & $\begin{array}{l}2.4 \\
1.0\end{array}$ & $\begin{array}{l}-29.0 \\
-29.8\end{array}$ & $\begin{array}{l}-27.8 \\
-27.1\end{array}$ & $\begin{array}{l}-1.2 \\
-2.7\end{array}$ & $\begin{array}{l}\mathrm{b} \\
\mathrm{b}\end{array}$ & $\begin{array}{l}28 \\
27\end{array}$ & $\begin{array}{r}89 \\
119\end{array}$ & $\begin{array}{l}61 \\
92\end{array}$ & $\begin{array}{l}1.8 \\
1.5\end{array}$ \\
\hline
\end{tabular}

${ }^{\mathrm{a}} \mathrm{Calculated}$ from total saturates fraction.

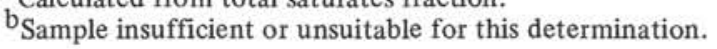



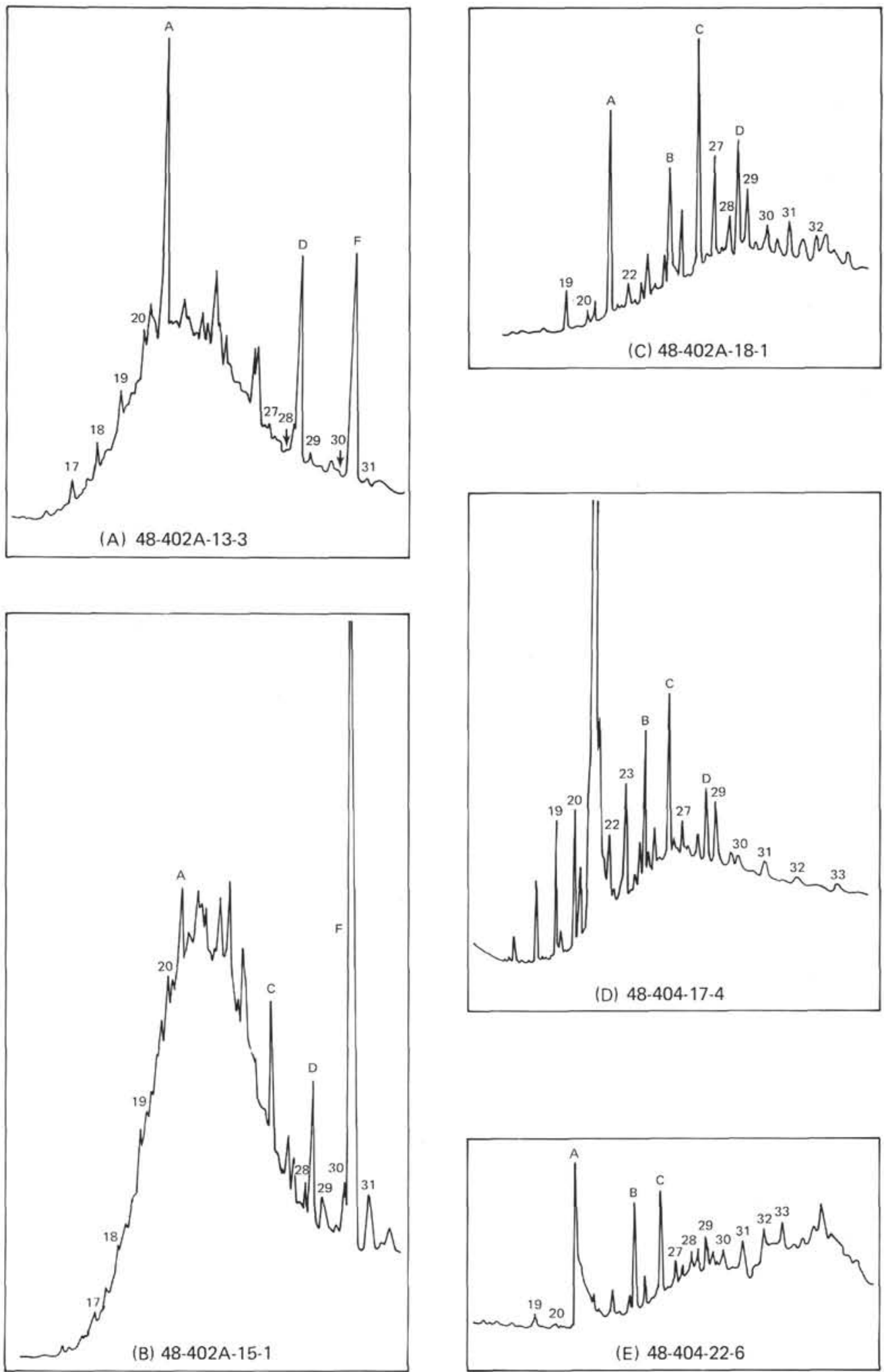

Figure 2. GC-profiles of the lipid fraction of Leg 48 cores. (A) $402 A-13-3$, (B) $402 A-15-1$, (C) $402 A-18-1$, (D) 404-17-4, and (E) 404-22-6.

\section{REFERENCES}

Scalan, R.S. and Smith, J.E., 1970. An improved measure of the odd-even predominance in the normal alkanes of sediment extracts and petroleum, Geochim. Cosmochim. Acta, v. 34, p. 611-630.
Erdman, J.G. and Schorno, K.S., 1978. Geochemistry of carbon: Deep Sea Drilling Project Leg 44. In Sheridan, R.E., Benson, W.E., et al., Initial Reports of the Deep Sea Drilling Project, v. 44: Washington (U.S. Government Printing Office), p. 605-616. 